Vol. 5 No. 4 (2021) pp. 398 - 406

Available online at: http://jurnal.umpwr.ac.id/index.php/abdimas/index

p-ISSN: $\underline{2580-3492}$ e-ISSN: 2581-0162

\title{
Mewujudkan Sistem Pendidikan Sekolah Ramah Anak Melalui Sosialisasi Komunikasi Organisasi di Sekolah Madrasah Ibtidaiyah Mathla'U1 Anwar Kabupaten Tangerang
}

\section{Nasaruddin Siregar, Hasyim Purnama, Sari Endah Nursyamsi, Nita Komala Dewi $\bowtie$}

Universitas Bhayangkara Jakarta Raya

Jl. Raya Perjuangan, Marga Mulya, Bekasi Utara, Indonesia

| nita.komala@dsn.ubharajaya.ac.id $\bowtie$ | DOI : https://doi.org/10.37729/abdimas.v5i4.1351 |

\begin{abstract}
Abstrak
Sekolah selain mengatur para pendidik dan tenaga pendidik juga harus memperhatikan sistem pendidikan yang diberikan kepada para siswa sehingga dapat berperilaku terpelajar. Salah satu sekolah yang sudah menerapkan sistem tersebut yakni Sekolah Madrasah Ibtidaiyah Mathla'Ul Anwar Kelurahan Cisauk, Kampung Cicayur, Kabupaten Tangerang akan tetapi belum sesuai dengan sistem pendidikan sekolah ramah anak sesuai ketentuan pemerintah yang mana adanya kerjasama antara pihak sekolah dan orang tua siswa untuk bisa mewujudkan sistem pendidikan sekolah ramah anak. Oleh karena itu maka perlu diberikan informasi tambahan mengenai sistem sekolah ramah anak dari segi komunikasi organisasi pihak sekolah dan peran guru serta orang tua siswa. Metode kegiatan abdimas dilaksanakan dengan tiga tahapan yakni melakukan persiapan, pelaksanaan, dan evaluasi. Tujuan kegiatan ini untuk meningkatkan pemahaman dan motivasi dalam penerapan komunikasi organisasi kepada guru dalam mewujudkan sistem sekolah ramah anak dan membantu meningkatkan peran guru dan orang tua dalam mewujudkan sekolah yang aman, nyaman, dan penuh kreatifitas anak untuk mewujudkan cita citanya. Kegiatan ini berjalan dengan lancar dan peserta bersikap antusias dalam menerima materi. Hasil kegiatan memberikan informasi tambahan kepada peserta mengenai komunikasi organisasi yang efektif dan efisien dalam lingkup sekolah dan pentingnya peran guru serta orang tua siswa dalam mewujudkan sekolah ramah anak. Kurangnya waktu dan kondisi yang tidak memungkinkan untuk lebih banyak memberikan informasi kepada peserta dalam pelaksanaan sehingga pemberian materi masih dirasakan kurang untuk itu diperlukannya kegiatan diskusi berkelanjutan agar lebih banyak lagi informasi yang didapat oleh peserta mengenai sistem sekolah ramah anak.
\end{abstract}

Kata Kunci: Komunikasi organisasi, Sekolah, Ramah anak

(c) (1) (9) This work is licensed under a Creative Commons Attribution-NonCommercial 4.0 International License

\section{Pendahuluan}

Beberapa tahun belakangan ini sering terjadi kekerasan terhadap anak, baik dilakukan oleh tenaga pengajar (guru) maupun anak sekolah terhadap anak sekolah lainnya. Dinas Pemberdayaan Perempuan, Perlindungan Anak Pengendalian Penduduk dan Keluarga Berencana (DP3AP2KB) mengatakan, "Sejauh ini masih ditemukan sejumlah kasus kekerasan terhadap anak tak hanya di lingkungan keluarga, tetapi juga di lingkungan sekolah, misalnya kekerasan yang melibatkan anak di lingkungan sekolah tercatat 14 kasus di Kota Tangerang. Adapun kasus yang kerap terjadi seperti pemalakan, hingga perundungan. Bahkan, ditemukan juga kasus anak mengusik guru, begitupun sebaliknya hingga memicu kekerasan"(Fauzi, 2019). 
Anak sebagai generasi penerus bangsa mempunyai tugas dalam pembangunan nasional. Penerus bangsa harus dapat tumbuh dan berkembang menjadi manusia dewasa yang sehat jasmani, rohani, berpendidikan, bermoral dan memiliki akhlak yang terpuji. Untuk mewujudkan kondisi seperti yang diinginkan maka perlu adanya kasih sayang dan pembinaan. Agar setiap anak kelak mampu memikul tanggungjawab, maka perlu mendapat kesempatan seluas-luasnya untuk tumbuh dan berkembang secara optimal baik fisik mental sosial, dan berakhlak mulia, perlu dilakukan upaya perlindungan serta untuk mewujudkan kesejahteraan anak dengan memberikan jaminan terhadap pemenuhan hak-haknya serta adanya perlakuan tanpa diskriminasi (Yosada \& Kurniati, 2019).

Berkaitan dengan kekerasan terhadap anak, menurut Data hasil riset Programme for International Students Assessment (PISA) 2018 menunjukkan murid yang mengaku pernah mengalami perundungan (bullying) di Indonesia sebanyak 41,1\%. Angka murid korban bully ini jauh di atas rata-rata negara anggota OECD yang hanya sebesar $22,7 \%$. Selain itu, Indonesia berada di posisi kelima tertinggi dari 78 negara sebagai negara yang paling banyak murid mengalami perundungan. Dikutip dari Detiknews.com, Wakil Ketua Komisi X Abdul Fikri Faqih menilai perundungan terjadi karena adanya masalah fisik, terutama untuk murid yang memiliki kebutuhan khusus. Selain mengalami perundungan, murid di Indonesia mengaku sebanyak 15\% mengalami intimidasi, 19\% dikucilkan, $22 \%$ dihina dan barangnya dicuri. Selanjutnya sebanyak $14 \%$ murid di Indonesia mengaku diancam, 18\% didorong oleh temannya, dan 20\% terdapat murid yang kabar buruknya disebarkan (Jayani, 2019). Berdasarkan Gambar 1, persentase murid korban bully di Indonesia menempati peringkat kelima tertinggi di dunia.

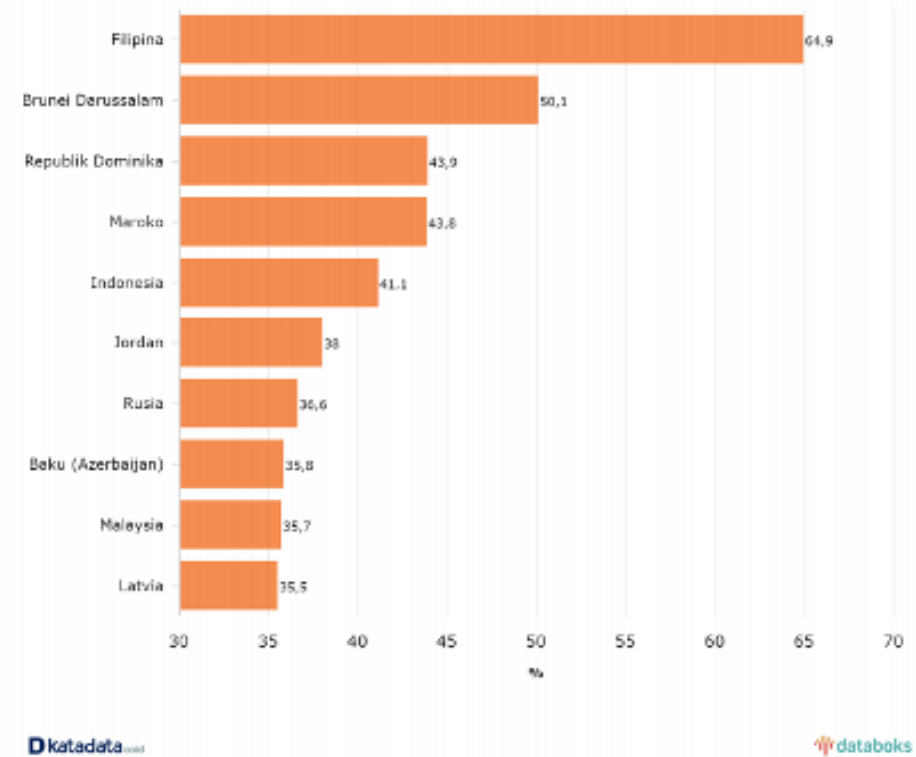

Gambar 1. Persentase murid yang mengalami perundungan (bully) 2018 PISA: murid korban 'bully' di Indonesia tertinggi kelima di dunia 
Bullying adalah bentuk-bentuk perilaku kekerasan dimana terjadi pemaksaan secara psikologis ataupun fisik terhadap seseorang atau sekelompok orang yang lebih "lemah" oleh seseorang atau sekelompok orang. Pelaku bullying yang biasa disebut bully bisa seseorang, bisa juga sekelompok orang, dan ia atau mereka mempersepsikan dirinya memiliki kekuatan/kekuasaan untuk melakukan apa saja terhadap korbannya. Korban juga mempersepsikan dirinya sebagai pihak yang lemah, tidak berdaya dan selalu merasa terancan oleh adanya bully (Djuwita, 2005 ; Ariesto 2009; Zakiyah et al., 2017).

Untuk mengurangi tingkat kenakalan remaja di sekolah maka sistem pendidikan pada sekolah selain mengatur para pendidik dan tenaga pendidik juga harus memperhatikan sistem pendidikan yang diberikan kepada para siswa sehingga dapat berperilaku terpelajar. Beberapa bentuk pencapaian prestasi akademik, menunjukkan perilaku yang beretika dan berakhlak mulia, memiliki motivasi belajar yang tinggi, kreatif, disiplin, bertanggung jawab, serta menunjukkan karakter diri sebagai warga masyarakat, warga negara dan bangsa merupakan bukti pelajar yang memiliki perilaku terpelajar.

Selain itu pengembangan bakat dan minat anak tidak dapat dilakukan dengan optimal tanpa adanya dukungan yang baik dari lingkungan sekitar, baik lingkungan keluarga, sekolah, maupun masyarakat. Tidak dapat dimungkiri bahwa lingkungan sekolah merupakan faktor yang memiliki andil dalam pemenuhan hak anak. Dalam hal ini tentu harapannya sekolah dapat memberikan layanan yang baik kepada anak demi berkembangnya anak secara optimal (Putri \& Akmal, 2019).

Beberapa aspek sarana dan prasarana yang dapat mendukung lingkungan yang kondusif dan mampu menurunkan tingkat kekerasan pada siswa dengan membuat zona aman dan selamat ke sekolah, adanya forum anak, ketersediaan pusat-pusat informasi layak anak, ketersediaan fasilitas kreatif dan rekreatif pada anak, ketersediaan kotak saran kelas dan sekolah, ketersediaan papan pengumuman, ketersediaan majalah atau koran anak. Sehingga sekolah memungkinkan anak untuk melakukan sesuatu yang meliputi hak untuk mengungkapkan pandangan dan perasaannya terhadap situasi yang memiliki dampak pada dirinya (Admin, 2019).

Berkaitan dengan hal tersebut di atas agar tercipta sekolah yang memiliki lingkungan yang kondusif sehingga tingkat kekerasan kepada anak menurun maka pemerintah bekerjasama dengan beberapa sekolah untuk membuat program sekolah ramah anak yang mengenal dan menghargai hak anak untuk memperoleh pendidikan, kesehatan, kesempatan bermain dan bersenang, melindungi dari kekerasan dan pelecehan, dapat mengungkapkan pandangan secara bebas, dan berperan serta dalam mengambil keputusan sesuai dengan kapasitas mereka. Sekolah juga menanamkan tanggung jawab untuk menghormati hak-hak orang lain, kemajemukan dan menyelesaikan masalah perbedaan tanpa melakukan kekerasan (Kementerian-PPPA, 2015).

Budaya/ kultur yang terbangun berdasarkan pembiasaan kehidupan sekolah yang kondusif dan bermartabat serta senantiasa menempatkan anak sebagai mitra pendidikan merupakan upaya dalam memberikan provisi, proteksi dan partisipasi kepada anak un- tuk tumbuh dan berkembang dalam komunitas yaitu masyarakat sekolah. Pemberian kebebasan berekspresi, beraktivitas dan mengembangkan minat bakat anak penting untuk diwujudkan melalui berbagai metode dan media (Kusdaryani et al., 2016). 
Dalam mendukung program pemerintah tersebut maka tim dosen dari Fakultas Ilmu Komunikasi akan melakukan kegiatan abdimas di sekolah Mathla'Ul Anwar dengan sistem sosialisasi mewujudkan sistem pendidikan sekolah ramah anak melalui komunikasi organisasi. Sistem sekolah ramah anak yang diprogramkan oleh pemerintah saat ini belum banyak diterapkan di sekolah-sekolah salah satunya di sekolah Mathla 'Ul Anwar. Sistem pendidikan sekolah ramah anak saat ini masih minim dikarenakan masih banyaknya siswa yang mendapatkan bullying di sekolah baik dari teman sejawat maupun guru mereka sendiri. Begitu juga dengan perlakuan dari orang tua mereka yang masih adanya kekerasan yang terjadi dalam rumah tangga terhadap anak mereka sendiri.

Pengertian komunikasi organisasi itu sendiri menurut (Bacal, 2004) menyatakan bahwa komunikasi organisasi yang efektif berkenaan dengan tiga hal. Pertama, semua pelaku harus memiliki keterampilan dan pemahaman yang tepat untuk berkomunikasi. Komunikasi bukan proses yang sederhana, dan banyak orang tidak memiliki pemahaman tentang isu komunikasi. Kedua, komunikasi organisasi yang efektif membutuhkan iklim atau budaya yang mendukung komunikasi yang efektif. Secara lebih khusus, iklim meliputi kepercayaan. Keterbukaan, penguatan praktek komunikasi yang baik, dan berbagi tanggung jawab untuk menciptakan komunikasi yang efektif. Ketiga, komunikasi yang efektif membutuhkan perhatian. Ini tidak begitu saja terjadi, tetapi dikembangkan sebagai hasil upaya intensional terhadap bagian manajemen dan staf (Zacharias, 2019).

Hambatan yang berkaitan dengan sistem sekolah ramah anak dengan komunikasi organisasi. Dimana komunikasi organisasi yang dimaksud komunikasi antara kepala sekolah dengan guru-guru dalam lingkup sekolah, seperti halnya bagaimana komunikasi organisasi antara kepala sekolah dengan guru-guru dalam merencanakan program sekolah ramah anak yang sesuai dengan acuan pemerintah ?, apakah ada unsur kepercayaan dari kepala sekolah kepada guru untuk bisa mendidik anak murid dengan rasa sayang seperti memberikan ilmu kepada anak mereka sendiri? apakah ada kenyamanan dari suasana pengajaran di dalam kelas saat proses belajar mengajar berlangsung ?.

Untuk itu, maka tim dosen bermaksud melakukan kegiatan Pengabdian Kepada Masyarakat mengenai mewujudkan sistem pendidikan sekolah ramah anak melalui sosialisasi komunikasi organisasi di sekolah Madrasah Ibtidaiyah Mathla 'Ul Anwar di kelurahan Cisauk, kampung Cicayur, kabupaten Tangerang. Sistem penyampaiannya dalam bentuk sosialisasi atau penyuluhan mengenai komunikasi organisasi yang efektif dan efiseien dalam lingkup sekolah dan peran guru dan orang tua siswa dalam mewujudkan sekolah ramah anak kepada peserta abdimas. Adapun tujuan khusus kegiatan ini adalah meningkatkan pemahaman dan motivasi dalam penerapan komunikasi organisasi di lingkup sekolah untuk mewujudkan sistem sekolah ramah anak dan peningkatan peran guru dan orang tua siswa dalam mewujudkan sekolah ramah anak yang aman, nyaman, dan penuh kreatifitas anak untuk mewujudkan cita citanya. 


\section{Metode}

Adapun sasaran dari kegiatan ini ialah tenaga pendidik, siswa dan orang tua siswa sebanyak 25 orang, maka sebagai rincian dari metode yang akan digunakan pada pelaksanaan abdimas ini secara runtut, tahapan kegiatan pengabdian ini mulai dari pembentukan tim hingga menentukan kebutuhan dan sasaran baru mengikuti alur kerja (Aribowo, 2018) seperti ditunjukkan pada Gambar 2.

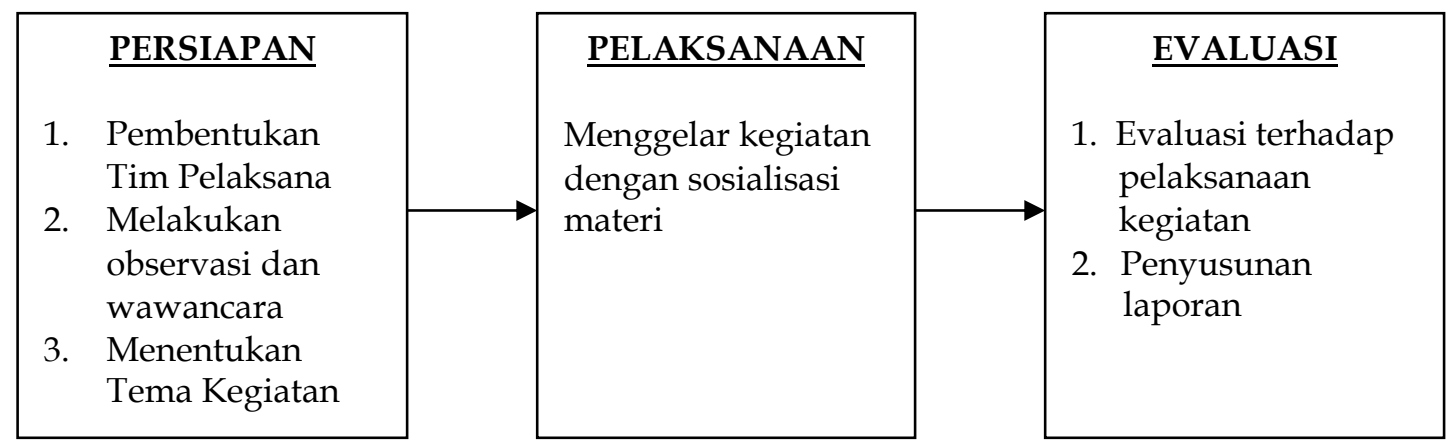

Gambar 2. Alur kegiatan PkM

\subsection{Persiapan}

Sebelum menentukan kegiatan dilakukan terlebih dahulu dengan pembentukan tim pelaksana. Tim pelaksana ini terdiri dari dosen tetap dan mahasiswa Fakultas Ilmu Komunikasi dari Universitas Bhayangkara Jakarta Raya. Langkah selanjutnya melakukan observasi yakni tim pelaksana menuju ke lokasi yang dituju sebagai tempat akan dilaksanakannya kegiatan abdimas. Kegiatan observasi ini dilaksanakan untuk melihat fenomena yang terjadi dilokasi sehingga tim bisa menentukan permasalahan untuk kegiatan. Selain itu dalam melaksanakan observasi tim juga melakukan beberapa wawancara singkat terkait mengenai problem/masalah/fenomena apa yang sedang terjadi di lokasi tersebut. Langkah dalam menentukan tema diambil dari hasil observasi dan wawancara singkat sehingga tim dapat menentukan tema mengenai sistem pendidikan sekolah ramah anak melalui komunikasi organisasi.

\subsection{Pelaksanaan}

Tahap berikutnya pelaksanaan kegiatan, dimana tim melaksanakan kegiatan dengan metode sosialisasi dalam bentuk pemberian materi/ceramah dan diskusi kepada peserta dengan menggunakan bahasa yang sederhana dan materi yang mudah dipahami. Tim pengabdi bertindak selaku narasumber memberikan materi mengenai 1). Komunikasi organisasi yang efektif dan efisien dalam lingkup sekolah, 2). Peran guru dan orang tua siswa dalam mewujudkan sistem sekolah ramah anak dan kegiatan ini berlangsung atas kerjasama dengan pihak sekolah Madrasah Ibtidaiyah Mathla'Ul Anwar kelurahan Cisauk, kampung Cicayur, kabupaten Tangerang.

Adapun dalam melaksanakan kegiatan ini terdiri dari beberapa tahapan yakni :

a. Pertama peserta diberikan materi mengenai komunikasi organisasi yang efektif dan efisien dalam lingkup sekolah.

b. Kedua, peserta diberikan waktu untuk diskusi/ bertanya kepada narasumber mengenai materi yang disampaikan. 
c. Ketiga, peserta diberikan materi mengenai peran guru dan orang tua siswa dalam mewujudkan sistem sekolah ramah anak.

d. Keempat, peserta diberikan waktu untuk diskusi/ bertanya kepada narasumber mengenai materi yang disampaikan.

e. Kelima, peserta diberikan kuisioner sebagai bahan evaluasi dari hasil pelaksanaan kegiatan sosialisasi. Evaluasi diberikan sebagai bahan masukan dan perbaikan untuk tahap selanjutnya yang dapat dilakukan oleh tim. Hasil tanya jawab/diskusi dan kuisioner merupakan data evaluasi yang diambil dari kegiatan pengabdian ini.

\subsection{Evaluasi}

Tahapan evaluasi merupakan tahapan akhir dari program kegiatan ini. Dari hasil evaluasi dapat diketahui bahwa peserta memahami materi yang narasumber sampaikan dan mendapatkan informasi tambahan mengenai sekolah ramah anak sesuai dengan yang dianjurkan oleh pemerintah dan mengetahui komunikasi yang efektif dan efisien dalam lingkup sekolah. Selain itu, evaluasi ini juga memberikan masukan kepada tim untuk bisa meningkatkan kegiatan sosialisasi sekolah ramah anak guna menekan jumlah kekerasan pada anak baik dilingkungan sekolah maupun rumah.

\section{Hasil dan Pembahasan}

Berdasarkan observasi dan fenomena yang terjadi saat ini mengenai permasalah kekerasan yang dialami oleh murid disekolah jumlahnya meningkat dan adanya peraturan dari pemerintah mengenai program sekolah ramah anak sebagai salah satu solusi untuk memperkecil jumlah kekerasan pada anak khususnya dilingkungan sekolah. Berkiatan dengan hal tersebut sekolah Madrasah Ibtidaiyah Mathla'Ul Anwar belum menerapkan program tersebut, sehingga tim tertarik untuk memberikan sosalisasi mengenai sistem program sekolah ramah anak melalui komunikasi organisasi sekolah. untuk itu tim memberikan solusi dari permasalah tersebut sebagai berikut :

\subsection{Presentasi Materi Abdimas}

Hasil dari pelaksanan kegiatan ini dituangkan dalam bentuk sosialisasi dengan memberikan informasi - informasi yang berkaitan dengan sistem pendidikan sekolah ramah anak melalui komunikasi organisasi. Pemberian informasi yang disampaikan oleh tim melalui pemaparan atau presentasi kepada peserta.

Pada tahapan awal pelaksanaan tim memberikan presentasi materi mengenai komunikasi organisasi dalam dunia pendidikan dibawakan oleh Bapak Drs. Nasaruddin Siregar, M.Si. Presentasi ini memberikan informasi kepada peserta mengenai bagaimana berkomunikasi dalam sebuah organisasi yang berada di dunia pendidikan. Muhammad (2007) menyatakan bahwa dengan adanya komunikasi yang baik suatu organisasi dapat berjalan lancar, sebaliknya jika tidak adanya komunikasi akan menimbulkan konflik antara anggota organisasi (Gibran, 2017). Komunikasi organisasi adalah proses pengiriman dan penerimaan berbagai pesan organisasi di dalam organisasi baik yang terjadi di dalam kelompok formal maupun kelompok informal di dalam organisasi (Safaria, 2004:133; Evi Zahara, 2018). Materi yang berikutnya mengenai peran guru dan orang tua dalam mewujudkan sekolah ramah anak yang dibawakan oleh Bapak Drs. Hasyim Purnama, M.Si. materi ini memberikan informasi kepada guru dan orang tua siswa untuk bisa bekerja sama dalam mewujudkan sekolah yang ramah anak. Program sekolah ramah anak ini tertuang 
dalam Peraturan Menteri Negara Pemberdayaan Perempuan dan Perlindungan Anak Republik Indonesia Nomor 8 Tahun 2014 tentang Kebijakan Sekolah Ramah Anak.

Hasil yang diperoleh dari presentasi ini diantaranya :

a. Peserta mengikuti kegiatan presentasi dengan baik dan bersemangat

b. Adanya informasi mengenai pengetahuan dan pemahaman tentang komunikasi organisasi yang berkaitan dengan sistem sekolah ramah anak dalam bentuk berkomunikasi antara kepala sekolah, guru dan orang tua dalam pembuatan perencanaan program sekolah ramah anak.

c. Adanya respon yang baik (feedback) dari peserta dalam bentuk diskusi/ tanya jawab serta permintaan untuk dapat diberikan arahan lebih lanjut tentang sekolah ramah anak.

Adapun penjelasan bentuk presentasi dalam kegiatan ini tertera pada Gambar 3a. dan untuk kegiatan diskusi ada pada Gambar 3b.

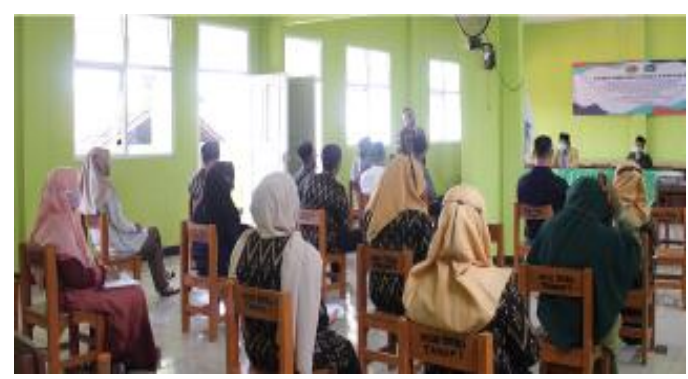

(a)

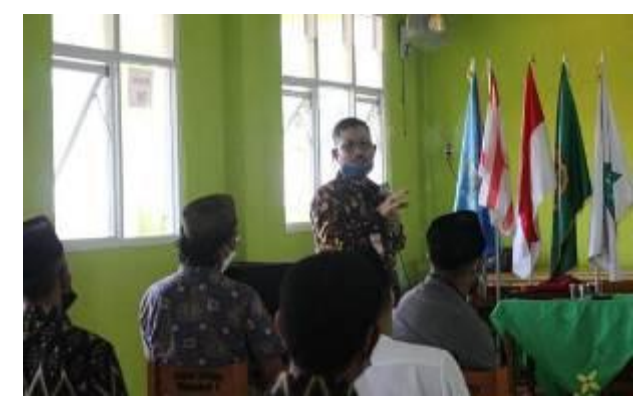

(b)

Gambar 3. (a) Presentasi materi, (b) Diskusi/ tanya jawab

\subsection{Komunikasi organisasi dalam mendukung program sekolah ramah anak}

Penyampaian materi dengan sistem sosialisasi mengenai komunikasi organisasi dalam dunia pendidikan yang bertujuan agar pihak sekolah mampu mengkomunikasikan pesan atau informasi mengenai perkembangan ataupun permasalahan yang dihadapi oleh pihak sekolah kepada pihak internal maupun pihak eksternal dapat berjalan dengan baik sehingga dapat meminimalis kesalahpahaman. Komunikasi organisasi yang baik khususnya didalam organisasi sekolah antara kepala sekolah dengan guru harus ditingkatkan dengan menggunakan media rapat internal sekolah guna informasi yang ada didalam proses belajar mengajar berjalan dengan baik.

Banyaknya asumsi mengenai pendisiplinan bukan hukuman dan konsekuensi bukan sanksi serta perbanyak apresiasi dalam tata tertib yang membuat masyarakat khususnya tenaga pendidik dan orang tua yang salah memahaminya. Berkaitan dengan banyaknya asumsi tersebut sehingga membuat jumlah kekerasan pada anak meningkat khususnya didunia pendidikan. Untuk itu, komunikasi organisasi didalam mendukung program sekolah ramah anak ini diharapkan selalu dilakukan oleh pihak sekolah dengan pihak eksternal demi menciptakan lingkungan sekolah yang aman bagi murid.

Program sekolah ramah anak yang mudah diterapkan dimana situasi sekolah Bersih, Aman, Ramah, Indah, Inklusif, Sehat, Asri, dan Nyaman. Dalam Peraturan Menteri Negara Pemberdayaan Perempuan dan Perlindungan Anak Republik Indonesia Nomor 8 Tahun 2014 tentang Kebijakan Sekolah Ramah Anak, dijelaskan bahwa dalam mewujudkan Sekolah Ramah Anak (SRA) ada enam indikator yang dikembangkan untuk mengukur capaian SRA. Indikator tersebut meliputi: 1) kebijakan SRA, 2) pelaksanaan kurikulum, 3) pendidikan dan tenaga kependidikan terlatih hak-hak anak, 
4) sarana dan prasarana SRA, 5) partisipasi anak, dan 6) partisipasi orang tua, lembaga masyarakat, dunia usaha, pemangku kepentingan lainnya, dan alumni. idealnya keenam indikator tersebut harus dipenuhi dalam rangka mewujudkan SRA (Putri \& Akmal, 2019).

\subsection{Evaluasi kegiatan dalam bentuk kuisioner}

Tahapan akhir dalam kegiatan ini tim abdimas memberikan kuisioner sebagai bentuk luaran dari kegiatan ini. Sistem penilaian ini untuk mengetahui apakah materi yang disampaikan oleh tim abdimas sesuai dengan kebutuhan peserta. Adapun hasil survey tersebut dijelaskan oleh Gambar 4.

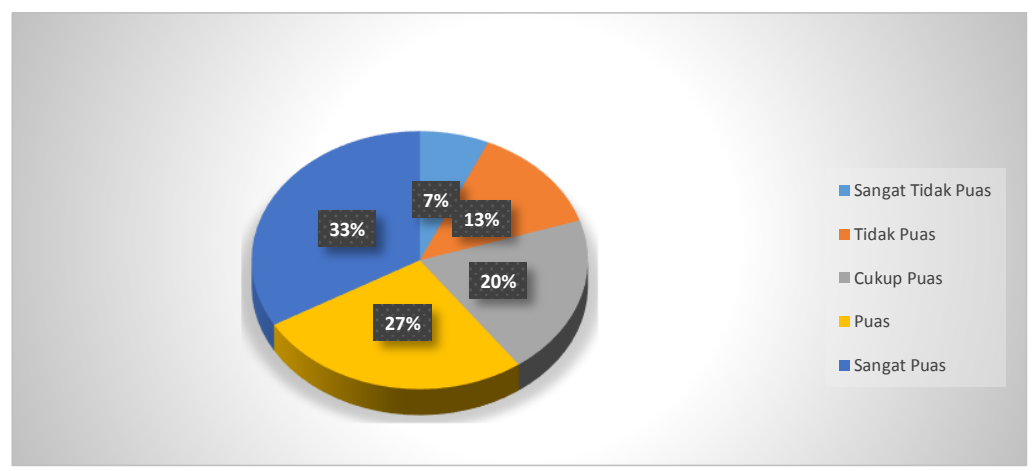

Gambar 4 . Hasil evaluasi kegiatan

Berdasarkan hasil evaluasi mitra dalam kegiatan menyatakan puas dan materi yang disampaikan sangat bermanfaat, terutama bagaimana mewujudkan sekolah yang ramah terhadap peserta didik dan terhindar dari hal-hal yang bersifat desktruktif bagi perkembangan kognitif, afektif, dan psikomotorik peserta didik. Dengan demikian tujuan kegiatan PkM telah tercapai dan untuk tahapan selanjutnya akan dilaksanakan pendampingan secara berkesinambungan antara pihak pengabdi dan sekolah.

\section{Kesimpulan}

Berdasarkan hasil dari kegiatan pengabdian kepada masyarakat yang telah dilakukan oleh tim ditemukannya permasalahan mengenai ketidak pahaman dari guru dan orang tua siswa mengenai sistem sekolah ramah anak. Dengan adanya kegiatan sosialisasi dan diskusi mengenai komunikasi organisasi dalam dunia pendidikan dan peran guru dan orang tua dalam sekolah ramah anak ini memberikan banyak informasi tambahan kepada para guru dan orang tua siswa. Rasa antusias dari guru dan orang tua terlihat dari aktifnya diskusi antara tim dengan peserta. Untuk itu tim pengabdian memberikan saran kepada kepala sekolah agar komunikasi organisasi dalam dunia pendidikan itu selalu dapat di terapkan dan program sekolah ramah anak ini dapat diwujudkan sesuai dengan arahan pemerintah. Bagi pengkaji selanjutnya agar sering melakukan sosialisasi program sekolah ramah anak pada sekolah yang memiliki jumlah tingkat kekerasan dalam lingkungan sekolahnya tinggi guna informasi yang disampaikan tepat sasaran. 


\section{Daftar Pustaka}

Admin. (2019). Deklarasi Sekolah Ramah Anak. Retrieved from http://www.sman5tamsel.sch.id/index.php/berita/detail/320/deklarasi-sekolahramah-anak

Aribowo, E. K. (2018). Digitalisasi Aksara Jawa Dan Pemanfaatannya Sebagai Media Pembelajaran Bagi Musyawarah Guru Mata Pelajaran Bahasa Jawa Smp Kabupaten Klaten. Warta LPM, 21(2), 59-70. https://doi.org/10.23917/warta.v21i2.5620

Evi Zahara. (2018). Peranan Komunikasi Organisasi Pimpinan Organisasi. Peranan Komunikasi Organisasi Bagi Pimpinan Organisasi, 1829-7463(April), 8.

Fauzi, A. I. (2019). Antisipasi Kekerasan, Guru di Tangerang Diminta Pelajari Kenakalan Anak. Retrieved from TangerangNews.com website: https://www.tangerangnews.com/kota-tangerang/read/29334/AntisipasiKekerasan-Guru-di-Tangerang-Diminta-Pelajari-Kenakalan-Anak

Gibran, H. (2017). Related Papers. Over The Rim, 191-199. https://doi.org/10.2307/j.ctt46nrzt.12

Jayani, D. H. (2019). PISA : Murid Korban’ Bully' di Indonesia Tertinggi Kelima di Dunia. $\quad$ Databoks, 2019. Retrieved from http://databoks.katadata.co.id/datapublish/2019/12/12/pisa-murid-korban-bully-diindonesia-tertinggi-kelima-di-dunia

Kementerian-PPPA. (2015). Panduan Sekolah Ramah Anak Deputi Tumbuh Kembang Anak.

Kusdaryani, W., Purnamasari, I., \& Tika Damayani, A. (2016). Penguatan Kultur Sekolah Untuk Mewujudkan Pendidikan Ramah Anak. Jurnal Cakrawala Pendidikan, 1(1), 125-133. https://doi.org/10.21831/cp.v1i1.8383

Napitupulu, D. S. (2019). Komunikasi Organisasi Pendidikan Islam. At-Ta'dib: Jurnal Ilmiah Prodi Pendidikan Agama Islam, 11(2), 127-136.

Putri, A., \& Akmal, A. (2019). Sekolah Ramah Anak: Tantangan dan Implikasinya Terhadap Pemenuhan Hak Anak. Journal of Civic Education, 2(4), 228-235. https://doi.org/10.24036/jce.v2i4.190

Wuryandani, W., \& Senen, A. (2018). Jurnal Civics : Media Kajian Kewarganegaraan. $15(1)$.

Yosada, K. R., \& Kurniati, A. (2019). MENCIPTAKAN SEKOLAH RAMAH ANAK, $145-154$.

Zacharias, T. (2019). Efektivitas komunikasi organisasi pada dinas pendidikan dan kebudayaan provinsi maluku. Jurnal Komunikasi Profesional, 3(2), 92-116. https://doi.org/10.25139/jkp.v3i2.2002

ZAKIYAH, E. Z., HUMAEDI, S., \& SANTOSO, M. B. (2017). Faktor Yang Mempengaruhi Remaja Dalam Melakukan Bullying. Prosiding Penelitian Dan Pengabdian Kepada Masyarakat, $\quad 4(2), \quad 324-330$. https://doi.org/10.24198/jppm.v4i2.14352 